\title{
The influence of surrounding land cover on wetland habitat conditions: a case study of inland wetlands in South Korea
}

Ran-Young Im ${ }^{1}$, Taekyu Kim ${ }^{2}$, Chung-Yeol Baek ${ }^{3}$, Chang-Su Lee ${ }^{3}$, Song-Hyun Kim ${ }^{3}$, Jung-Hwan Lee ${ }^{3}$, Ji Yoon Kim ${ }^{4}$, Gea-Jae Joo ${ }^{\text {Corresp. } 1}$

${ }^{1}$ Department of Integrated Biological Sciences, Pusan National University, Busan, South Korea

2 Global Environment Research Division, National Institute of Environmental Research, Incheon, South Korea

3 National Wetlands Center, National Institute of Environmental Research, Changnyeong, Gyeongnam, South Korea

4 Center for Climate Change Adaptation, National Institute for Environmental Studies, Tsukuba, Ibaraki, Japan

Corresponding Author: Gea-Jae Joo

Email address: gjjoo@pusan.ac.kr

Wetland ecosystems have been globally degraded and lost due to rapid urbanization and climate change. An assessment of national scale inventory, including wetland types and conditions, is urgently required to understand the big picture of endangered wetlands, such as where they are and how they look like. We analyzed the spatial patterns of each inland wetland type (brackish wetland was included) in South Korea and the relative importance of land cover categories on wetland conditions. The wetlands were grouped into four dominant types (riverine, lake, mountain, and human-made) according to their topography. Riverine wetlands constituted the largest area (71.3\%). The relative ratio of wetlands in a well-conserved condition (i.e., " $A$ " rank) was highest in riverine wetlands $(23.8 \%)$, followed by mountain wetlands $(22.1 \%)$. The higher proportion of grasslands was related to a better condition ranking, but the increasing bareland area had a negative impact on wetland conditions. We also found that wetlands located near wetland protected areas tend to be in a better condition compared to remote sites. Our results further support the importance of the condition of surrounding areas for wetland conservation. 
1 The influence of surrounding land cover on wetland 2 habitat conditions: a case study of inland wetlands in 3 South Korea

6 Ran-Young $\mathrm{Im}^{1}$, Taekyu Kim ${ }^{2}$, Chung-Yeol Baek ${ }^{3}$, Chang-Su Lee ${ }^{3}$, Song-Hyun Kim³ ${ }^{3}$ Jung-

7 Hwan $\mathrm{Lee}^{3}$, Ji Yoon Kim${ }^{4}$, Gea-Jae Joo ${ }^{*}$

8

$9{ }^{1}$ Department of Integrated Biological Sciences, Pusan National University, Busan, Republic of

10 Korea

$11{ }^{2}$ Global Environment Research Division, National Institute of Environmental Research, Incheon,

12 Republic of Korea

$13{ }^{3}$ National Wetlands Center, National Institute of Environmental Research, Changnyeong,

14 Gyeongnam, Republic of Korea

$15{ }^{4}$ Center for Climate Change Adaptation, National Institute for Environmental Studies, Tsukuba, 16 Ibaraki, Japan

Email address: gjjoo@pusan.ac.kr 


\section{Abstract}

24 Background. Wetland ecosystems have been globally degraded and lost due to rapid urbanization and climate change. An assessment of national scale inventory, including wetland types and conditions, is urgently required to understand the big picture of endangered wetlands, such as where they are and how they look like.

Methods. We analyzed the spatial patterns of each inland wetland type (brackish wetland was included) in South Korea and the relative importance of land cover categories on wetland conditions. The wetlands were grouped into four dominant types (riverine, lake, mountain, and human-made) according to their topography.

Results. Riverine wetlands constituted the largest area $(71.3 \%)$. The relative ratio of wetlands in a well-conserved condition (i.e., "A" rank) was highest in riverine wetlands (23.8\%), followed by mountain wetlands $(22.1 \%)$. The higher proportion of grasslands was related to a better condition ranking, but the increasing bareland area had a negative impact on wetland conditions. We also found that wetlands located near wetland protected areas tend to be in a better condition compared to remote sites. Our results further support the importance of the condition of surrounding areas for wetland conservation.

Key words Catchment management, Rapid assessment, Spatial pattern, Wetland condition assessment, Wetland inventory

\section{Introduction}

Globally, natural ecosystems are being converted for human use such as food production, road construction, and urban habitation (Foley, 2005). Human-induced land cover change is one of the most direct and influential factors resulting in the decline of biodiversity (Falcucci, Maiorano \& Boitani, 2007; Newbold et al., 2015; Sala et al., 2000). Inland wetlands in freshwater ecosystems in particular have been rapidly degraded and connectivity among wetland habitats has decreased due to population growth and related anthropogenic development (Davidson, 2014; Gibbs, 2000; Mori, Onoda \& Kayaba, 2018). Wetland habitat conditions are closely related to the species richness, functions, and associated services of wetland ecosystems (Engelhardt and Ritchie, 2001). Wetland biodiversity is further affected by land-use attributes around wetlands (Findlay \& Bourdages, 2000; Houlahan et al., 2006), and surrounding areas also serve an important supporting function to wetlands (Mitsch \& Gosselink, 2000). The benefits and positive functions of wetlands have been well recognized and the needs for their conservation have been highly suggested (Gibbons et al., 2006; Juffe-Bignoli et al., 2014; Maltby, 1991).

National wetland inventories are important as a first step to improve management plan and policy-making for wetland conservation; because they can provide an overview of the recent status including distribution, condition, and potential threats (Gardner \& Finlayson, 2018; Hu et al., 2017; Kingsford, Basset \& Jackson, 2016). To understand the status of wetland ecosystems, a wetland inventory has been carried on diverse spatial scales such as national, regional, and local (Davidson \& Finlayson, 2007; Finlayson, Davidson \& Stevenson, 2001; Finlayson \& van der 
Valk, 1995; Kloiber et al., 2015). Furthermore, diverse wetland assessments have been used to understand the ecological condition (Guidugli-Cook et al., 2017), functional value of wetlands (Fennessy, Jacobs \& Kentula, 2007), ecosystem services (Costanza et al., 2007; Yang et al., 2008), and wetland health (Beuel et al., 2016). Although implementation of wetland inventory has been increased since 2000 s, only $44 \%$ of the Ramsar Convention participants have yet to establish national inventories. The rate is higher in North America (67\%) and Europe (62\%), while in Asia region only $30 \%$ of participating countries established their national wetland inventory (Gardner \& Finlayson, 2018).

The assessment of wetland condition or function (e.g., Hydrogeomorphic Wetland Classification; HGM or Rapid Assessment; RA) can be utilized for the effective management and conservation of wetland ecosystems (Fennessy, Jacobs \& Kentula, 2007). There have been several trials of rapid assessment of wetlands in South Korea (Choi et al., 2017; Hong \& Kim, 2017; Koo \& Kim, 2001); however nationwide assessment has been limited. For a comprehensive understanding of wetland condition in East-Asian region, it is necessary to organize national-level wetland inventory and information on current wetland condition in this region.

South Korea is one of the regions where land use is rapidly transforming, as it is elsewhere in East Asia, and wetland habitats are disappearing due to recent economic development. The agricultural conversion constituted the largest part of wetland loss during the 1930s in South Korea. Reclamations for the construction of roads and industrial complexes were rapidly increased in the late 1980 s (Im et al., 2017). About $60 \%$ of floodplain wetlands developed in the lower Nakdong River disappeared in the last 90 years. The increasing pressure to modify aquatic infrastructure (i.e., levees, dams, channels, etc.) has threatened wetland ecosystems. In order to understand the distribution of wetlands and their general conditions, the Ministry of the Environment (MOE) and the National Institute of Environmental Research (NIER) conducted a wetland survey project since 2000. The MOE and NIER surveyed spatial information, type classification, and wetland condition. However, spatial patterns of wetland types, wetland conditions, and their relationships with the surrounding environments were not well understood. Considering the rate of urbanization and the loss of natural wetlands in recent decades, information on the spatial context of wetland distribution and the influence of land use on wetland condition is necessary to prioritize conservation management for different wetland types.

In this study, we identified 1) distribution and extent of wetland and 2) analyzed the spatial patterns of wetland types and 3 ) the relationship between wetland conditions and surrounding environments to identify factors that influence the condition of wetlands in South Korea. Our goal was to understand overall condition of different types of wetlands in the study region and compare the relative importance of landscape components on wetland condition. We utilized wetland condition rankings from the wetland inventory database established by the MOE and NIER. The relative influence of environmental variables including elevation, land cover (urban area, cropland, forest, grassland, bareland, and water), population density, distance from 
103

104

105

106

107

108

109

110

111

112

113

114

115

116

117

118

119

120

121

122

123

124

125

126

127

128

129

130

131

132

133

134

135

136

137

138

139

140

141

142

rivers, and distance from protected areas were explored to test the effect of the socio-physical environment on the habitat condition of various wetland types. We hypothesized the rank of wetland condition is closely related to the surrounding environmental conditions in watersheds.

\section{Materials \& Methods}

\section{Wetland database}

We utilized nationwide survey records of inland wetlands organized by the MOE and NIER (NIER, 2018). This wetland database includes the field survey results of 2,499 sites from 2000 to 2015 . The spatial coverage of the wetland database is the inland wetlands (brackish wetland was included) distributed in the national boundary of South Korea (N $32^{\circ} 07^{\prime} 22^{\prime \prime} \sim 38^{\circ}$ $36^{\prime} 40^{\prime \prime}$, E $124^{\circ} 36^{\prime} 36^{\prime \prime} \sim 131^{\circ} 52^{\prime} 22^{\prime \prime}$ ). We used wetland types, polygon data of wetland delineation, geographical coordinates (GPS point), and the wetland condition rankings of each wetland.

The MOE used a modified wetland type classification system of the Ramsar Convention to suit the wetland characteristic of South Korea (MOE, 2010). This classification system grouped various types of inland wetlands into four major categories (i.e., riverine, lake, mountain, and human-made). It includes 25 sub-wetland types based on the environmental characteristics of topography, soil, water sources, vegetation, and other hydrologic traits which are important for wetland formation and maintenance. However, some wetland types were only identified at limited sites and they share similar environmental settings with other wetland types. In this study, inland wetlands share characteristics at level IV (i.e., hydrology, soil, and vegetation), which were integrated and 15 sub-wetland types were used for the following analysis (Table 1).

To define the wetland characteristics and classify types of wetlands, experienced wetland researchers, including two field crew members of geologists (or hydrologists) and botanists conducted field investigations from April 2000 to October 2015 (MOE, 2011). In the field, the survey team marked the potential boundary of a wetland on a printed aerial map based on vegetation and sediment conditions. GPS coordinates of extreme points of the boundary of the wetland were also recorded using handheld GPS devices (position accuracy: $<1 \mathrm{~m}$; AKN1MBT/GLONASS, Ascen GPS, ROK). Based on the field survey results, the GIS-team delineated the boundary of wetlands in the GIS database. This wetland DB targeted a wetland larger than $400 \mathrm{~m}^{2}$ that can be identified in aerial photographs at 1:5,000 scale. A georeferenced field drawing of the wetland boundary was used as a draft line for the following process. The MOE set the delineation guidelines for each wetland type at level II categories (Table 1; MOE, 2010). For example, the boundary of riverine- and lake-type wetlands was essentially set based on the sediment condition and development of the wetland plant communities. The outer boundary line was set to the highest water level during flooding or it was set to the line of the dike or levee if present. The delineation of mountain-type wetlands was primarily determined by the sub-catchment area and the development of wetland vegetation (i.e., Alnus spp., Salix spp., Moliniopsis japonica Hack., Carex spp.). 
We further used the results of the wetland condition survey from the wetland database of the MOE, described in the previous section. The wetland condition was assessed by scoring the diverse aspect of site conditions using relative scale criteria. The assessment was composed of eight different categories ( six common categories for all types of wetlands, and two specific categories for each type). The common categories include 1) wetland size, 2) representativeness of type characteristic, 3) level of physical modification, 4) academic or educational value (i.e., proximity to educational or research facilities, potential or current use as an ecological-learning site or ecological monitoring site, easy-accessibility for citizens), 5) diversity of wetland wildlife and presence of endangered species, and 6) invasion level of exotic species. For riverine-type wetlands, 1) periods of wetland formation (i.e., $<1$ year, 1-5, 5-10, 10-30, and $\geq 30$ years) and 2) landscape value (i.e., characteristic riverine topography, point bar, oxbow, and meandering channel) were included in the evaluation criteria. For lake-type wetlands, 1) the ratio of aquatic vegetation in the open water area (i.e., $<20 \%, 20-40 \%, 40-60 \%, 60-80 \%$, and $\geq 80 \%$ ) and 2 ) economic or cultural activities by local people (i.e., fishery, agricultural water, and historic sites) were included. For mountain-type wetlands, 1) the presence of peat layer and 2) soil saturation were included. Evaluation categories in wetland condition assessment were selected from that of a rapid assessment method modified by Koo \& Kim (2001) and MOE (2011). The purpose of the assessment was to evaluate the priority of wetlands conservation and to determine the necessity for an intensive survey to proceed with the designation of a protected area (MOE, 2011).

Each evaluation category was scored using five-point Likert scales (Tam et al., 2017). A higher score (five point) was related to the better condition of wetland environments. Each wetland site was classified into four ranking groups based on the average score of eight evaluation categories (Table 2). By using raw scoring data for wetland conditions from 2000 to 2010 (during the first 10 years), the MOE tested the distribution of total scores and defined criteria of four ranks as described in Table 2. Rank " $A$ " represents wetlands in a well-conserved condition, which had the highest score with more than half of the evaluation criteria. Rank " $\mathrm{B}$ " includes wetlands with an average score higher than 2.8. Rank " $\mathrm{C}$ " indicates wetlands that require moderate enhancement to recover to a healthy condition. Sites with an average value of less than 2.0 were evaluated with rank " $D$ " where sites were severely modified and active restoration practices would be required to recover its previous status.

\section{Wetland distribution analysis}

We calculated the central point and size of wetlands by using the polygon data of the wetland delineation database. These vector data of each wetland were used to extract the spatial pattern in the following analysis. To understand the distribution pattern of wetland condition rankings, we applied a kernel density function and calculated the relative frequency of the wetland condition ranking (\%) in a catchment area by using ArcMap (v 10.1, ESRI, USA).

\section{Analysis of factors affecting wetland rankings}


182

183

184

185

186

187

188

189

190

191

192

193

194

195

196

197

198

199

200

201

202

203

204

205

206

207

208

209

210

211

212

213

214

215

216

217

218

219

220

221

The associations between wetland condition rankings (A-D) and environmental variables were analyzed with multinomial regression models. Previous studies reported the significant influence of watershed environments compared to the influence of a distance-based buffered area (Croft-White et al., 2017). We used a catchment polygon from the Korean Reach File version 3.0 produced by the Water Information System of the MOE (http://water.nier.go.kr/front/riverNetwork/riverNetwork.jsp). This catchment DB divided the extent of our study sites into 117 sub-level catchments.

We considered environment variables such as elevation, the relative percentage of land cover class, population, distance from a river, and distance from a wetland protected area designated by MOE as explanatory variables. The elevation (El. $\mathrm{m}$ ) of each wetland was extracted from the digital elevation model produced by the National Geographic Information Institute (https://www.ngii.go.kr/eng/main.do). The distance from the river and wetland protected area was calculated using the Euclidian distance function of the spatial analysis tool. We used log-transformed values for elevation, distance to the river and distance to the wetland protected area. The land cover data used a 1:50,000 scale map classified into seven categories (urban area, cropland, forest, grassland, wetland, bareland, and water) published by the MOE in 2000. The relative percentage of surrounding land cover ( $\%$ ) and population density (individuals per $\mathrm{km}^{2}$ ) was calculated by using a spatial analysis tool based on the catchment area of each wetland.

Before the regression analysis was conducted, the multicollinearity among variables was determined by calculating the variance inflation factors (VIF). Variables with $<10$ VIF remained in the analysis (Table S1). The regression models were run separately for different wetland types. We reported $\exp (\beta)$ (odds ratio), 95\% confidence intervals (CI) for $\exp (\beta), \mathrm{p}$-values, and $R^{2}$ (Nagelkerke's) of the final regression model. An analysis of the multinomial regression and variance inflation factors were performed using IBM SPSS statistics software (version 20, IBM Corp., Armonk, NY, USA).

\section{Results}

\section{Spatial patterns of wetlands}

The sum of the identified wetland area was $734.4 \mathrm{~km}^{2}$ and the size largely varied from $0.05 \mathrm{~km}^{2}$ to $58 \mathrm{~km}^{2}$ (Fig. 1A). A large portion of the wetlands (about $90 \%$ of the total) was distributed at a low elevation $(<150$ El. m). Regionally, the overall density of wetlands was higher in the western part of the Korean Peninsula, where the elevation was lower and agricultural intensity was higher (Fig. 1B). Three major river channels also run through the western region. The southeastern part, a tributary of the Nakdong River, also has a high density of wetlands sites. Near the metropolitan cities, the number of remaining wetlands was relatively low compared to rural areas (Fig. 1C).

Riverine-type wetlands had the largest area $\left(524.0 \mathrm{~km}^{2}, 71.3 \%\right.$ of the total), followed by lake $\left(137.1 \mathrm{~km}^{2}, 18.7 \%\right)$, human-made $\left(58.6 \mathrm{~km}^{2}, 8.0 \%\right)$, and mountain types $\left(14.6 \mathrm{~km}^{2}, 2.0 \%\right.$; Fig. 2). Lotic-type wetlands (R2) constituted the largest portion of riverine-type wetlands (409.3 $\mathrm{km}^{2}, 968$ sites), followed by brackish- (R1; $108.5 \mathrm{~km}^{2}, 28$ sites) and lentic-type wetlands (R3;

Peer) reviewing PDF | (2019:11:42704:2:0:NEW 2 Apr 2020) 
222

223

224

225

226

227

228

229

230

231

232

233

234

235

236

237

238

239

240

241

242

243

244

245

246

247

248

249

250

251

252

253

254

255

256

257

258

259

260

261

$6.2 \mathrm{~km}^{2}, 28$ sites). Freshwater lakes (L6) had the largest portion among the lake-type wetlands (71.8 km², 497 sites), followed by reclaimed lakes (L5; $56.4 \mathrm{~km}^{2}, 71$ sites), lagoons (L4; $6.8 \mathrm{~km}^{2}$, 20 sites), oxbow or dune slacks ( $7 ; 2.1 \mathrm{~km}^{2}, 50$ sites). The average size of reclaimed lakes was notably higher than other wetland types. Artificial dams or reservoirs (H12; $49.0 \mathrm{~km}^{2}, 211$ sites) constituted the largest portion of human-made wetland types. Retention ponds or urban parks (H15) covered $7.6 \mathrm{~km}^{2}$ (37 sites). Irrigation channels or fishing ponds (H14) and rice paddy wetlands (H13) covered $1.4 \mathrm{~km}^{2}$ (30 sites) and $0.7 \mathrm{~km}^{2}$ (12 sites), respectively. Fens (M9; 7.1 $\mathrm{km}^{2}, 139$ sites) were the dominant type of mountain wetland, followed by shrub dominant swamp or abandoned paddy fields (M11; $4.5 \mathrm{~km}^{2}, 327$ sites), bogs (M8; $2.0 \mathrm{~km}^{2}, 20$ sites), and marshes (M10; $0.9 \mathrm{~km}^{2}, 61$ sites).

\section{Assessment of wetland conditions}

Based on the relative evaluation criteria of wetland conditions, we assessed 2,497 wetland sites out of 2,499 sites identified from the previous survey (two sets of missing data). There was a total of 303 "A"-ranked wetlands (12.1\% of total; Figs. 3A and 3E), which represent those in a well-conserved condition. "A"-ranked wetlands were largely distributed near the wetland protected area in the northern (e.g., Hanbando wetland) and southern (e.g., Upo wetland) part. "B"- and "C"-ranked wetlands made up 938 (37.6\%) and 1,039 sites (41.6\%; Figs. 3B-3C, $3 F-3 G)$, respectively. "B"- and "C"-ranked wetlands were distributed broadly in the western part of the peninsula, where the relative percentage of agricultural fields is high. " $\mathrm{D}$ "-ranked wetlands, those that are in a severely modified or contaminated state, made up a total of 217 sites (8.7\%; Figs. 3D and H). "D"-ranked wetlands showed a high level of density in the two rural areas in the southern region. These areas were adjacent to the industrial complex. The density of "D"-ranked wetlands was higher in the metropolitan area which is related to a high population density (Fig. 3H). Comparisons among different wetland types identify distinct spatial patterns related to its origin and potential influence of urbanization (Figs. S1-S4). "A"-ranked riverine wetland and mountain wetland largely distributed in the upstream area and high elevated mountainous region, respectively. Regardless of wetland types, "D"-ranked wetland sites tended to distribute in urban areas or in suburban areas, where urban development was high.

The relative ratio of " $\mathrm{A}$ "-ranked wetlands was highest in the riverine type (23.8\%), followed by mountain (22.1\%), lake (14.2\%), and human-made (5.7\%) wetlands (Fig. 4). Bog (M8; 55.0\%) showed the highest rate for "A"-ranked wetlands. brackish wetlands (R1; 35.7\%) and lagoons (L4; $25.5 \%)$ also showed relatively good condition compared to other wetland types. Human-made wetland types recorded the lowest ratio for the higher two ranks and the highest ratio for the lower ranks. The relative ratio of " $D$ "-ranked wetlands was highest in the humanmade-type (18.1\%), followed by lake (10.8\%), mountain (8.4\%), and riverine wetlands (4.4\%).

\section{Factors affecting wetland condition rankings}

The regression model for riverine-type wetlands had a significant effect relative to the area of grassland (\%) and bareland (\%) in the watershed and distance from a wetland protected 
262

263

264

265

266

267

268

269

270

271

272

273

274

275

276

277

278

279

280

281

282

283

284

285

286

287

288

289

290

291

292

293

294

295

296

297

298

299

300

area $\left(R^{2}=0.16, \mathrm{~N}=1023, P<0.001\right.$; Table 3$)$. The area of grasslands in the watershed was about 1.67 ("A"-ranked), 1.91 ("B"-ranked), and 1.66 ("C"C-ranked) times higher than " $\mathrm{D}$ "ranked sites $(P<0.001)$; however, the area of bareland was 0.47 ("B"-ranked) and 0.62 ("C $\mathrm{C}$ "ranked) times lower in the riverine wetlands. Riverine wetlands located near the protected area in the watershed were tended to have a higher condition ranking. The rank of lake-type wetlands showed significant effects relating to the area of grassland and bareland $\left(R^{2}=0.17, \mathrm{~N}=631, P<\right.$ 0.001; Table 3). "B"-ranked lake-type wetlands had grassland areas that were 1.26 times larger in their watershed than " $\mathrm{D}$ "-ranked lakes. And the area of bareland of "C"-ranked lake-type wetlands was about 1.37 times larger than "D"-ranked sites. Elevation and distance to protected area affected the condition of the mountain-type wetlands $\left(R^{2}=0.19, \mathrm{~N}=547, P<0.001\right)$. Wetlands located at a high elevation $(\sim 1,216 \mathrm{~m})$ tended to have a higher condition ranking. "A"ranked mountain-type wetlands were located close distance to the protected area than " $D$ "ranked sites. Human-made wetlands with larger water and grassland areas in their watershed tend to have a better wetland condition.

\section{Discussion}

\section{Current condition of wetlands in South Korea}

Considering the number and area of wetlands, riverine-type wetland was the most dominant type (e.g., $71.3 \%$ of the total number) in the study region. River channels $(55.7 \%)$ and brackish wetlands $(14.8 \%)$ constituted the biggest portion of riverine-type wetlands. On the other hand, the relative number of floodplain wetlands in the riverine wetlands was low in our results $(0.8 \%)$, even though it is known as one of the highest value ecosystems on earth (Costanza et al., 1997). Floodplain wetlands have decreased globally (e.g., in Europe and North America: up to a 90\% loss; Australia: about a 50\% loss), and more than half of the area was lost due to conversion to agricultural fields and dam construction (Kingsford, 2000; Tockner \& Stanford, 2002). In South Korea, most of the floodplain wetlands were lost due to the construction of levees at a high elevation and the conversion of land to agricultural fields (Im et al., 2017). Recently, sixteen large weirs were newly built in the four major rivers and floodplains, further modifying the hydrologic condition of major river systems (Im et al., 2015).

Artificial wetlands (i.e., reservoirs, dams, lakes, rice paddies, artificial waterways, water purification ponds, etc.) were rated with the highest percentage of the lowest rank (C and D rank: $68.6 \%$ ), reflecting their degraded habitat condition compared to other wetland types. Most of the artificial wetlands were located close to cities or industrial complexes where anthropogenic activities were higher (Wu, Zhou \& Tian, 2017). Intense land use, pollution, and the drainage of water would have complexly influenced the condition of artificial wetlands. However, the number of these human-made wetlands has been increasing (Finlayson \& Spiers, 1999) and the importance of well-designed wetlands with proper management reflect the significant value of the wildlife that reside there as well as water quality improvement (Ghermandi et al., 2010). A detailed survey of the conservation status of human-made wetlands is required and adequate 
301

302

303

304

305

306

307

308

309

310

311

312

313

314

315

316

317

318

319

320

321

322

323

324

325

326

327

328

329

330

331

332

333

334

335

336

337

338

339

340

restoration or management plans need to focus on increasing the health of human-made wetlands.

Agricultural land occupied about 18.8\% (rice paddies $11.2 \%, 11,282.1 \mathrm{~km}^{2}$ ) of South Korea (KOSIS, 2018). Rice paddies were included in the category of wetland types; however, only part of the rice paddies managed by the national trust and abandoned fields were included in the current wetland inventory due to practical management reasons. In contrast with the US and Europe, rice paddies in Asia occupy a larger portion of the agricultural land area than dry crop fields. The diverse function of the rice paddy system, such as flood control, groundwater recharge, water quality, local climate mitigation, biodiversity, and culture and landscape has been supported by various studies (Natuhara, 2013; Settele et al., 2018). Contracting parties of the Ramsar Convention adopted the "Enhancing biodiversity in rice paddies as wetland systems" resolution during the 10th Ramsar Convention (2008). Organic farming, winter flooding, and Biodiversity Management Contracts further enhanced the ecological function of rice paddy ecosystems. Considering the diverse benefits of rice ecosystem services in Asia, following wetland evaluation systems need to reflect the distinct characteristics of the rice paddy system.

\section{Importance of surrounding land cover in catchments}

We found 1) the positive influence of grassland, elevation, and protected areas on wetland conditions and 2) the negative influence of bareland in the catchment area. Landscape modification and pollution induced by human society have been steadily increasing and it has caused the massive loss of wetland ecosystems (Beuel et al., 2016; Gibbs, 2000). Depending on the types of wetlands, the land use pattern influences the condition of wetlands in various ways (Vörösmarty et al., 2010). Other studies showed that the proportion (\%) of agricultural fields (Heady et al., 2015; Stapanian, Gara \& Schumacher, 2018) and urban areas (Haidary et al., 2013; Houlahan \& Findlay, 2003) in surrounding areas negatively affected the biological conditions of wetlands. Forests had a positive influence on mitigating water quality degradation (Sliva \& Williams, 2001) and maintaining biodiversity (Houlahan et al., 2006) and the quality of wetland vegetation (Stapanian, Gara \& Schumacher, 2018). Our results showed that the high frequency (\%) of grasslands in the catchment area positively affected the condition rank of wetlands regardless of wetland type. Grassland with a dense vegetation cover has higher soil retention capacity (Fu et al., 2011). Thus, its soil erosion control service prevents sediment inflow into rivers or wetlands in the catchment area and helps to improve water quality (Brazier, Bilotta \& Haygarth, 2007). Besides, grassland around wetlands can provide more natural habitats with a synergistic effect for enhanced biodiversity (Naugle et al., 2001). Overall, the results imply the importance of natural vegetation in the catchment area (Bengtsson et al., 2019; Smith \& Haukos, 2002). On the other hand, the high proportion of bareland (i.e., areas with no vegetation and bare soil) negatively influenced wetland condition rankings. Bareland is known to have higher soil erosion rates than other types of land cover (Cerdan et al., 2010), and the sediment flows into the wetland increases internal turbidity and reduces light transmission (Wantzen \& Mol, 2013). Besides, dormant eggs (e.g., invertebrate) or seeds can be buried by sedimentation resulting in 
341

342

343

344

345

346

347

348

349

350

351

352

353

354

355

356

357

358

359

360

361

362

363

364

reduced survival rate; a higher rate of soil erosion can negatively affect the sustainability of wildlife in wetlands (Gleason RA et al., 2003). Considering various land use factors (i.e., agriculture, urban areas, forest, and vegetation) related to wetland conditions, it seems that the significant land use factors affecting wetland conditions can be diverse depending on the landscape characteristics of the catchment area and wetland types.

The proximity to the protected wetland area notably showed a positive influence on the condition ranking of riverine and mountain-type wetlands. Barber et al. (2014) reported that protected areas had the effect of mitigating disturbances even in the surrounding areas. McDonald et al. (2007) reported that the rate of land conservation increased within $2 \mathrm{~km}$ of the protected area, and the newly established protected area tended to be located close to previous protected areas. The positive adjacent influence of protected areas on the surrounding area needs to be concurrently considered as synergistic with regional conservation practices (Beatty et al., 2014).

\section{Recommendations for wetland management}

The necessity of wetland inventory has become important in providing effective conservation plans. We showed that an evaluation of wetland conditions with relative scoring can be used to make the protection or rehabilitation area a priority in order to enhance the condition of degraded wetlands. However, there has been a gap in the available quantitative information due to short surveys and lack of clarity in the evaluation of wetland condition. Majority of academic surveys have been spatially biased in conservation areas or proximate sites from research institutes. The absence of quantitative measurements in most wetland sites limits a detailed evaluation of wetland conditions. To compensate for this issue, we suggest the utilization of historical literature, including NGO surveys, academic reports, and land use records from the past. There were several successful attempts to integrate and mine new information by using this historical information (Griffin, 2017; Kim, Joo \& Do, 2018), and these practices would be beneficial to compensate for the results of the initial assessment.

Wetland conditions are sensitive to direct environmental change (i.e., water quality, reclamation) within the wetlands, and can also be negatively affected by land cover changes in surrounding areas (Stapanian, Gara \& Schumacher, 2018). Current studies supported the direct and indirect influence of land use changes in the watershed (Croft-White et al., 2017). Richardson et al. (2011) found that upstream restoration efforts had a positive influence on the downstream water quality of rivers and wetlands. Our results further stress the importance of an integrated watershed approach for the successful management and restoration of wetlands.

In addition, our results showed that five of the wetland types (i.e., brackish wetlands, riverine, floodplains, bog, and fen) are maintaining better conditions (\% of "A+B"-ranked: 60 $89 \%$ ) compared to other wetland types. Freshwater lake, marsh, and abandoned paddy field in high elevation area had a higher portion of degraded wetland sites ("C+D" ranked: 60-64\%). Conservation management should consider this biased situation among different types of wetlands. And conservation efforts to improve surrounding land use conditions with a natural 
381

382

383

384

385

386

387

388

389

390

391

392

393

394

395

396

397

398

399

400

401

402

403

404

405

406

407

408

409

410

411

412

413

414

415

416

417

418

419

420

421

area (e.g., grassland) are required to support wetland conditions. Finally, expanding and maintaining wetland conservation areas could enhance the overall condition by strengthening habitat networks in the watershed.

\section{Conclusion}

Establishing national wetland inventory and identifying the spatial pattern of wetland condition is important for effective wetland conservation. In this study, we mapped the inland wetlands in South Korea and evaluated the overall condition of wetlands based on the rapid assessment method. We expect our results will provide a rough estimation of the wetland status in the study region and can be a basis to plan effective conservation schemes. We also found that wetland condition was influenced by the land cover condition in sub-watersheds. Based on this finding, we stress the importance of considering land cover characteristics in the watershed to protect diverse types of wetland habitats.

\section{Acknowledgements}

We would like to express our sincere thanks to the researchers who participated in field surveys for the inland wetland research project (General Survey of National Inland Wetlands, Monitoring for National Inland Wetland) conducted by the National Institute of Environmental Research (NIER).

\section{References}

Barber CP, Cochrane MA, Souza CM, Laurance WF. 2014. Roads, deforestation, and the mitigating effect of protected areas in the Amazon. Biological Conservation 177:203-209. DOI: 10.1016/j.biocon.2014.07.004.

Beatty WS, Kesler DC, Webb EB, Raedeke AH, Naylor LW, Humburg DD. 2014. The role of protected area wetlands in waterfowl habitat conservation: implications for protected area network design. Biological Conservation 176:144-152. DOI: 10.1016/j.biocon.2014.05.018

Bengtsson J, Bullock JM, Egoh B, Everson C, Everson T, O'Connor T, O'Farrell PJ, Smith HG, Lindborg R. 2019. Grasslands-more important for ecosystem services than you might think. Ecosphere 10: e02582. DOI: 10.1002/ecs2.2582

Beuel S, Alvarez M, Amler E, Behn K, Kotze D, Kreye C, Leemhuis C, Wagner K, Willy DK, Ziegler S, Becker M. 2016. A rapid assessment of anthropogenic disturbances in East African wetlands. Ecological Indicators 67:684-692. DOI: 10.1016/j.ecolind.2016.03.034.

Brazier RE, Bilotta GS, Haygarth PM. 2007. A perspective on the role of lowland, agricultural grasslands in contributing to erosion and water quality problems in the UK. Earth Surface Processes and Landforms 32:964-967. DOI: 10.1002/esp.1484

Cerdan O, Govers G, Le Bissonnais Y, Van Oost K, Poesen J, Saby N, Gobin A, Vacca A, Quinton J, Auerswald K, Klik A, Kwaad FJPM, Raclot D, Ionita I, Rejman J, Rousseau S, Muxart T, Roxo MJ, Dostal T. 2010. Rates and spatial variations of soil erosion in Europe: a study based on erosion plot data. Geomorphology 122:167-177. DOI: 10.1016/j.geomorph.2010.06.011. 
422

423

424

425

426

427

428

429

430

431

432

433

434

435

436

437

438

439

440

441

442

443

444

445

446

447

448

449

450

451

452

453

454

455

456

457

458

459

460

461

462

Choi J-Y, Kim S-K, Yun J-H, Joo G-J. 2017. Wetland assessment and improvement of evaluation index using Rapid Assessment Method (RAM). Korean Journal of Ecology and Environment 50:314-324. DOI: 10.11614/KSL.2017.50.3.314

Costanza R, d'Arge R, Groot R de, Farber S, Grasso M, Hannon B, Limburg K, Naeem S, O’Neill RV, Paruelo J, Raskin RG, Sutton P, Belt M van den. 1997. The value of the world's ecosystem services and natural capital. Nature 387:253-260. DOI: $10.1038 / 387253 \mathrm{a} 0$.

Costanza R, Fisher B, Mulder K, Liu S, Christopher T. 2007. Biodiversity and ecosystem services: A multi-scale empirical study of the relationship between species richness and net primary production. Ecological Economics 61:478-491. DOI:

10.1016/j.ecolecon.2006.03.021.

Croft-White MV, Cvetkovic M, Rokitnicki-Wojcik D, Midwood JD, Grabas GP. 2017. A shoreline divided: Twelve-year water quality and land cover trends in Lake Ontario coastal wetlands. Journal of Great Lakes Research 43:1005-1015. DOI: 10.1016/j.jglr.2017.08.003.

Davidson NC. 2014. How much wetland has the world lost? Long-term and recent trends in global wetland area. Marine and Freshwater Research 65:934-941. DOI: 10.1071/MF14173.

Davidson NC, Finlayson CM. 2007. Earth observation for wetland inventory, assessment and monitoring. Aquatic Conservation: Marine and Freshwater Ecosystems 17:219-228. DOI: 10.1002/aqc.846.

Engelhardt KAM, Ritchie ME. 2001. Effects of macrophyte species richness on wetland ecosystem functioning and services. Nature 411:687-689. DOI: 10.1038/35079573.

Falcucci A, Maiorano L, Boitani L. 2007. Changes in land-use/land-cover patterns in Italy and their implications for biodiversity conservation. Landscape Ecology 22:617-631. DOI: 10.1007/s10980-006-9056-4.

Fennessy MS, Jacobs AD, Kentula ME. 2007. An evaluation of rapid methods for assessing the ecological condition of wetlands. Wetlands 27:543-560. DOI: 10.1672/02775212(2007)27[543:AEORMF]2.0.CO;2.

Findlay CST, Bourdages J. 2000. Response time of wetland biodiversity to road construction on adjacent lands. Conservation Biology 14:86-94. DOI: 10.1046/j.1523-1739.2000.99086.x.

Finlayson CM, Davidson N, Stevenson NJ. 2001. Wetland inventory, assessment, and monitoring: practical techniques and identification of major issues: proceedings of Workshop 4, 2nd International Conference on Wetlands and Development, Dakar, Senegal, 8-14 November 1998, Supervising Scientist Report 161. Darwin: Supervising Scientist.

Finlayson CM, Spiers AG (eds.). 1999. Global review of wetland resources and priorities for wetland inventory, Supervising Scientist Report 144. Canberra: Supervising Scientist.

Finlayson CM, van der Valk AG. 1995. 14. Wetland classification and inventory: A summary. Vegetatio 118:185-192. DOI: 10.1007/BF00045199.

Foley JA. 2005. Global consequences of land use. Science 309:570-574. DOI: 10.1126/science. 1111772 .

Peer) reviewing PDF | (2019:11:42704:2:0:NEW 2 Apr 2020) 
463

464

465

466

467

468

469

470

471

472

473

474

475

476

477

478

479

480

481

482

483

484

485

486

487

488

489

490

491

492

493

494

495

496

497

498

499

500

501

502

Fu BJ, Liua Y, Lü Y, He C, Zeng Y, Wu B. 2011. Assessing the soil erosion control service of ecosystems change in the Loess Plateau of China. Ecological Complexity 8: 284-293. DOI: 10.1016/j.ecocom.2011.07.003Gardner RC, Finlayson M. 2018. Global wetland outlook: State of the world's wetlands and their services to people 2018. Switzerland: Ramsar Convention Secretariat.

Ghermandi A, Bergh JCJM van den, Brander LM, Groot HLF de, Nunes PALD. 2010. Values of natural and human-made wetlands: A meta-analysis. Water Resources Research 46:1-12. DOI: $10.1029 / 2010$ WR009071.

Gibbons JW, Winne CT, Scott DE, Willson JD, Glaudas X, Andrews KM, Todd BD, Fedewa LA, Wilkinson L, Tsaliagos RN, Harper SJ, Greene JL, Tuberville TD, Metts BS, Dorcas ME, Nestor JP, Young CA, Akre T, Reed RN, Buhlmann KA, Norman J, Croshaw DA, Hagen C, Rothermel BB. 2006. Remarkable amphibian biomass and abundance in an isolated wetland: implications for wetland conservation. Conservation Biology 20:14571465. DOI: $10.1111 / \mathrm{j} .1523-1739.2006 .00443 . x$.

Gibbs JP. 2000. Wetland loss and biodiversity conservation. Conservation Biology 14:314-317. DOI: $10.1046 / j .1523-1739.2000 .98608 . x$.

Gleason RA, Euliss NH, Hubbard DE, Duffy WG. 2003. Effects of sediment load on emergence of aquatic invertebrates and plants from wetland soil egg and seed banks. Wetlands 23:2634. DOI: 10.1672/0277-5212(2003)023[0026:EOSLOE]2.0.CO;2.

Griffin E. 2017. Rescue old data before it's too late. Nature 545:267. DOI: 10.1038/545267a.

Guidugli-Cook M, Richter SC, Scott BJ, Brown DR. 2017. Field-based assessment of wetland condition, wetland extent, and the National Wetlands Inventory in Kentucky, USA. Wetlands Ecology and Management 25:517-532. DOI: 10.1007/s11273-017-9533-3.

Haidary A, Amiri BJ, Adamowski J, Fohrer N, Nakane K. 2013. Assessing the impacts of four land use types on the water quality of wetlands in Japan. Water Resources Management 27:2217-2229. DOI: 10.1007/s11269-013-0284-5.

Heady WN, Clark RP, O'Connor K, Clark C, Endris C, Ryan S, Stoner-Duncan S. 2015. Assessing California's bar-built estuaries using the California Rapid Assessment Method. Ecological Indicators 58:300-310. DOI: 10.1016/j.ecolind.2015.05.062.

Hong MG, Kim JG. 2017. An analysis of trends in wetland function assessments and further suggestions. Journal of Wetlands Research 19:1-15. DOI: 10.17663/JWR.2017.19.1.001

Houlahan JE, Findlay CS. 2003. The effects of adjacent land use on wetland amphibian species richness and community composition. Canadian Journal of Fisheries and Aquatic Sciences 60:1078-1094. DOI: 10.1139/f03-095.

Houlahan JE, Keddy PA, Makkay K, Findlay CS. 2006. The effects of adjacent land use on wetland species richness and community composition. Wetlands 26:79-96. DOI: 10.1672/0277-5212(2006)26[79:TEOALU]2.0.CO;2.

Hu S, Niu Z, Chen Y, Li L, Zhang H. 2017. Global wetlands: potential distribution, wetland loss, and status. Science of the Total Environment 586:319-327. DOI: 10.1016/j.scitotenv.2017.02.001. 
503

504

505

506

507

508

509

510

511

512

513

514

515

516

517

518

519

520

521

522

523

524

525

526

527

528

529

530

531

532

533

534

535

536

537

538

539

540

541

542

Im R-Y, Kim JY, Choi J-Y, Do Y, Joo G-J. 2015 Changes of river morphology in the mid-lower part of Nakdong River basin after the 4 Large River Project, South Korea. Korean Journal of Ecology and Environment 48:188-194. DOI: 10.11614/KSL.2015.48.3.188.

Im R-Y, Kim JY, Joo G-J, Do Y. 2017. Process of wetland loss in the lower Nakdong River, South Korea. Applied Ecology and Environmental Research 15:69-78. DOI: 10.15666/aeer/1501_069078.

Juffe-Bignoli D, Burgess ND, Bingham H, Belle EMS, de Lima MG, Deguignet M, Bertzky B, Milam AN, Martinez-Lope J, Lewis E, Eassom A, Wicander S, Geldmann J, van Soesbergen A, Arnell AP, O'Connor B, Park S, Shi YN, Danks FS, MacSharry B, Kingston N. 2014. Protected planet report 2014. UK: UNEP-WCMC: Cambridge.

Kim JY, Joo G-J, Do Y. 2018. Meta-analysis of site distribution and researcher network of the Korean Society of Limnology: 1968 2017. The Korean Society of Limnology 51:124-134. DOI: $10.11614 /$ KSL.2018.51.1.124.

Kingsford RT. 2000. Ecological impacts of dams, water diversions and river management on floodplain wetlands in Australia. Austral Ecology 25:109-127. DOI: 10.1046/j.14429993.2000.01036.x.

Kingsford RT, Basset A, Jackson L. 2016. Wetlands: conservation's poor cousins. Aquatic Conservation: Marine and Freshwater Ecosystems 26:892-916. DOI: 10.1002/aqc.2709.

Kloiber SM, Macleod RD, Smith AJ, Knight JF, Huberty BJ. 2015. A semi-automated, multisource data fusion update of a wetland inventory for East-Central Minnesota, USA. Wetlands 35:335-348. DOI: 10.1007/s13157-014-0621-3.

Koo B-H \& Kim K-G. 2001. A study on the assessment for the functions of inland wetlands using RAM (Rapid Assessment Method). Journal of the Korean Society of Environmental Restoration Technology 4:38-48

KOSIS (Korean Statistical Information Service). 2018. Available at http://kosis.kr/statisticsList (accessed 25 June 2018).

Maltby E. 1991. Wetland management goals: wise use and conservation. Landscape and Urban Planning 20:9-18. DOI: 10.1016/0169-2046(91)90085-Z.

McDonald RI, Yuan-Farrell C, Fievet C, Moeller M, Kareiva P, Foster D, Gragson T, Kinzig A, Kuby L, Redman C. 2007. Estimating the effect of protected lands on the development and conservation of their surroundings. Conservation Biology 21:1526-1536. DOI: 10.1111/j.1523-1739.2007.00799.x.

Mitsch WJ, Gosselink JG. 2000. The value of wetlands: importance of scale and landscape setting. Ecological Economics 35:25-33. DOI: 10.1016/S0921-8009(00)00165-8.

MOE. 2010. A study on classification of national wetlands and wetland restoration (in Korean). Gwacheon: Ministry of Environment

MOE. 2011. Survey guideline for national inland wetlands (in Korean). Gwacheon: Ministry of Environment

Mori T, Onoda Y, Kayaba Y. 2018. Geographical patterns of flow-regime alteration by floodcontrol dams in Japan. Limnology 19:53-67. DOI: 10.1007/s10201-017-0518-y. 
543

544

545

546

547

548

549

550

551

552

553

554

555

556

557

558

559

560

561

562

563

564

565

566

567

568

569

570

571

572

573

574

575

576

577

578

579

580

581

Natuhara Y. 2013. Ecosystem services by paddy fields as substitutes of natural wetlands in Japan. Ecological Engineering 56:97-106. DOI: 10.1016/j.ecoleng.2012.04.026.

Naugle DE, Johnson RR, Estey ME, Higgins KF. 2001. A landscape approach to conserving wetland bird habitat in the prairie pothole region of eastern South Dakota. Wetlands 21:117. DOI: 10.1672/0277-5212(2001)021[0001:ALATCW]2.0.CO;2.

Newbold T, Hudson LN, Hill SLL, Contu S, Lysenko I, Senior RA, Börger L, Bennett DJ, Choimes A, Collen B, Day J, De Palma A, Díaz S, Echeverria-Londoño S, Edgar MJ, Feldman A, Garon M, Harrison MLK, Alhusseini T, Ingram DJ, Itescu Y, Kattge J, Kemp V, Kirkpatrick L, Kleyer M, Correia DLP, Martin CD, Meiri S, Novosolov M, Pan Y, Phillips HRP, Purves DW, Robinson A, Simpson J, Tuck SL, Weiher E, White HJ, Ewers RM, Mace GM, Scharlemann JPW, Purvis A. 2015. Global effects of land use on local terrestrial biodiversity. Nature 520:45-50. DOI: 10.1038/nature14324.

NIER. 2018. Open Data Portal. Available at https://www.data.go.kr/dataset/3038409/fileData.do (assessed 25 July 2018)

Richardson CJ, Flanagan NE, Ho M, Pahl JW. 2011. Integrated stream and wetland restoration: A watershed approach to improved water quality on the landscape. Ecological Engineering 37:25-39. DOI: 10.1016/j.ecoleng.2010.09.005.

Sala OE, Chapin FS, Armesto JJ, Berlow E, Bloomfield J, Dirzo R, Huber-Sanwald E, Huenneke LF, Jackson RB, Kinzig A, Leemans R, Lodge DM, Mooney HA, Oesterheld M, Poff NL, Sykes MT, Walker BH, Walker M, Wall DH. 2000. Global biodiversity scenarios for the year 2100. Science 287:1770-1774.

Settele J, Heong KL, Kühn I, Klotz S, Spangenberg JH, Arida G, Beaurepaire A, Beck S, Bergmeier E, Burkhard B, Brandl R, Bustamante JV, Butler A, Cabbigat J, Le XC, Catindig JLA, Ho VC, Le QC, Dang KB, Escalada M, Dominik C, Franzén M, Fried O, Görg C, Grescho V, Grossmann S, Gurr GM, Hadi BAR, Le HH, Harpke A, Hass AL, Hirneisen N, Horgan FG, Hotes S, Isoda Y, Jahn R, Kettle H, Klotzbücher A, Klotzbücher T, Langerwisch F, Loke W-H, Lin Y-P, Lu Z, Lum K-Y, Magcale-Macandog DB, Marion G, Marquez L, Müller F, Nguyen HM, Nguyen QA, Nguyen VS, Ott J, Penev L, Pham HT, Radermacher N, Rodriguez-Labajos B, Sann C, Sattler C, Schädler M, Scheu S, Schmidt A, Schrader J, Schweiger O, Seppelt R, Soitong K, Stoev P, Stoll-Kleemann S, Tekken V, Thonicke K, Tilliger B, Tobias K, Andi Trisyono Y, Dao TT, Tscharntke T, Le QT, Türke M, Václavík T, Vetterlein D, Villareal S 'Bong', Vu KC, Vu Q, Weisser WW, Westphal C, Zhu Z, Wiemers M. 2018. Rice ecosystem services in South-east Asia. Paddy and Water Environment 16:211-224. DOI: 10.1007/s10333-018-0656-9.

Sliva L, Williams DD. 2001. Buffer Zone versus Whole Catchment Approaches to Studying Land Use Impact on River Water Quality. Water Research 35:3462-3472. DOI: 10.1016/S0043-1354(01)00062-8.

Smith LM, Haukos DA. 2002. Floral diversity in relation to Playa Wetland area and watershed disturbance. Conservation Biology 16:964-974. DOI: 10.1046/j.1523-1739.2002.00561.x 
582

583

584

585

586

587

588

589

590

591

592

593

594

595

596

597

598

599

600

601

602

603

604
Stapanian MA, Gara B, Schumacher W. 2018. Surrounding land cover types as predictors of palustrine wetland vegetation quality in conterminous USA. Science of The Total Environment 619-620:366-375. DOI: 10.1016/j.scitotenv.2017.11.107.

Tam JC, Link JS, Rossberg AG, Rogers SI, Levin PS, Rochet M-J, Bundy A, Belgrano A, Libralato S, Tomczak M, van de Wolfshaar K, Pranovi F, Gorokhova E, Large SI, Niquil N, Greenstreet SPR, Druon J-N, Lesutiene J, Johansen M, Preciado I, Patricio J, Palialexis A, Tett P, Johansen GO, Houle J, Rindorf A. 2017. Towards ecosystem-based management: identifying operational food-web indicators for marine ecosystems. ICES Journal of Marine Science 74:2040-2052. DOI: 10.1093/icesjms/fsw230.

Tockner K, Stanford JA. 2002. Riverine flood plains: present state and future trends. Environmental Conservation 29:308-330. DOI: 10.1017/S037689290200022X.

Vörösmarty CJ, McIntyre PB, Gessner MO, Dudgeon D, Prusevich A, Green P, Glidden S, Bunn SE, Sullivan CA, Liermann CR, Davies PM. 2010. Global threats to human water security and river biodiversity. Nature 467:555-561. DOI: 10.1038/nature09440.

Wantzen KM, Mol JH. 2013. Soil erosion from agriculture and mining: a threat to tropical stream ecosystems. Agriculture 3: 660-683. DOI: 10.3390/agriculture3040660.

Wu W, Zhou Y, Tian B. 2017. Coastal wetlands facing climate change and anthropogenic activities: A remote sensing analysis and modelling application. Ocean \& Coastal Management 138:1-10. DOI: 10.1016/j.ocecoaman.2017.01.005.

Yang W, Chang J, Xu B, Peng C, Ge Y. 2008. Ecosystem service value assessment for constructed wetlands: A case study in Hangzhou, China. Ecological Economics 68:116125. DOI: $10.1016 /$ j.ecolecon.2008.02.008. 


\section{Table $\mathbf{1}$ (on next page)}

Classification of inland wetlands (brackish wetland was included) in South Korea.

Inland wetlands were sub-categorized at four different levels based on the traits of topography, hydrology, soil, and vegetation. 
1 Table 1

2 Classification of inland wetlands (brackish wetland was included) in South Korea. Inland

3 wetlands were sub-categorized at four different levels based on the traits of topography,

4 hydrology, soil, and vegetation.

\begin{tabular}{|c|c|c|c|c|}
\hline Level I & $\begin{array}{l}\text { Level II } \\
\text { (topography) }\end{array}$ & $\begin{array}{c}\text { Level III } \\
\text { (water source) }\end{array}$ & $\begin{array}{c}\text { Level IV } \\
\text { (hydrology, soil, vegetation) }\end{array}$ & $\begin{array}{c}\begin{array}{c}\text { Reference } \\
\text { number }\end{array} \\
\end{array}$ \\
\hline \multirow{11}{*}{$\begin{array}{c}\text { Inland } \\
\text { wetlands }\end{array}$} & \multirow{3}{*}{ Riverine } & Brackish & Estuarine/deltas/salt marsh & $\mathrm{R} 1$ \\
\hline & & Lotic zone & Rivers/streams/creeks & $\mathrm{R} 2$ \\
\hline & & Lentic zone & Floodplain & R3 \\
\hline & \multirow{4}{*}{ Lake } & \multirow{2}{*}{ Brackish } & Lagoon & L4 \\
\hline & & & Reclaimed lake & L5 \\
\hline & & \multirow{2}{*}{ Freshwater } & Freshwater lake & L6 \\
\hline & & & Oxbow/dune slack & $\mathrm{L} 7$ \\
\hline & \multirow{4}{*}{ Mountain } & Precipitation & Bog & M8 \\
\hline & & $\begin{array}{c}\text { Subsurface } \\
\text { water }\end{array}$ & Fen & M9 \\
\hline & & & Marsh & M10 \\
\hline & & $\begin{array}{l}\text { Subsurface } \\
\text { /surface water }\end{array}$ & $\begin{array}{c}\text { Shrub dominant swamp } \\
\text { /abandoned paddy field in high } \\
\text { elevation area }\end{array}$ & M11 \\
\hline \multirow{4}{*}{$\begin{array}{l}\text { Human- } \\
\text { made } \\
\text { wetlands }\end{array}$} & \multirow{4}{*}{-} & Artificial lake & Artificial dam/reservoir & $\mathrm{H} 12$ \\
\hline & & \multirow{2}{*}{$\begin{array}{l}\text { Agricultural· } \\
\text { inland fishery } \\
\text { purpose }\end{array}$} & Rice paddy & $\mathrm{H} 13$ \\
\hline & & & Irrigation channel/fishing pond & H14 \\
\hline & & Constructed & Retention pond/urban parks & $\mathrm{H} 15$ \\
\hline
\end{tabular}

5 
Table 2 (on next page)

A judgment criteria for an assessment of wetland condition rankings.

The assessment comprised eight categories and was scored using five-point Likert scales. 


\section{Table 2}

2 A judgment criteria for an assessment of wetland condition rankings. The assessment comprised

3 eight categories and was scored using five-point Likert scales.

\begin{tabular}{|c|c|c|}
\hline Rank & Criteria & $\begin{array}{c}\text { Conservation } \\
\text { priority }\end{array}$ \\
\hline A & $\begin{array}{l}\text { - Score of "5" is more than } 1 / 2 \text { of the total assessment criteria } \\
\text { - Scores of type-specific criteria are both " } 5 \text { " } \\
\text { - Important habitat for endangered wildlife, core habitat of legally protected } \\
\text { species }\end{array}$ & $\begin{array}{c}\text { Absolute } \\
\text { conservation }\end{array}$ \\
\hline B & $\begin{array}{l}\text { The average of total score: } \geq 2.8 \\
\text { - Score of " } 5 " \text { is more than } 1 / 4 \text { of the total assessment criteria } \\
\text { - Score of " } 4 \text { " is more than } 1 / 2 \text { of the total assessment criteria } \\
\text { - Scores of type-specific criteria are both }>4 \\
\text { - Sites fulfill the requirement for an "A" ranking, but had temporal (not } \\
\text { permanent) degradation or damage }\end{array}$ & Conservation \\
\hline $\mathrm{C}$ & $\begin{array}{l}\text { - The average of total score: } 2.0 \sim 2.7 \\
\cdot \text { At least one criteria is scored "5" } \\
\text { - Score of " } 3 \text { " is more than } 1 / 2 \text { of the total assessment criteria }\end{array}$ & $\begin{array}{l}\text { Conservation and } \\
\text { wise usage }\end{array}$ \\
\hline D & $\begin{array}{l}\cdot \text { The average of total score: }<2.0 \\
\text { Sites have been permanently damaged or undergone severe modification }\end{array}$ & $\begin{array}{l}\text { Restoration } \\
\text { or use }\end{array}$ \\
\hline
\end{tabular}

4 


\section{Table 3 (on next page)}

Multinomial logistic regression model of wetland condition rankings with characteristics of surrounding environments.

Models were run separately with different wetlands types, and rank " $D$ " was used as the reference category. $\operatorname{Exp}(\beta)$ means odd ratio and how many times the value of explanatory variables increases compared to that of " $D$ " rank. 


\section{Table 3}

2 Multinomial logistic regression model of wetland condition rankings with characteristics of

3 surrounding environments. Models were run separately with different wetlands types, and rank

4 "D" was used as the reference category. $\operatorname{Exp}(\beta)$ means odd ratio and how many times the value 5 of explanatory variables increases compared to that of " $D$ " rank.

\begin{tabular}{|c|c|c|c|c|c|c|c|c|c|}
\hline \multirow{2}{*}{ Rank } & \multirow{2}{*}{ Variables } & \multicolumn{2}{|c|}{ Riverine (n=1023) } & \multicolumn{2}{|c|}{ Lake $(n=631)$} & \multicolumn{2}{|c|}{ Mountain $(n=547)$} & \multicolumn{2}{|c|}{ Human-made $(\mathrm{n}=290)$} \\
\hline & & $\operatorname{Exp}(\beta)$ & $95 \% \mathrm{CI}$ & $\operatorname{Exp}(\beta)$ & $95 \% \mathrm{CI}$ & $\operatorname{Exp}(\beta)$ & $95 \% \mathrm{CI}$ & $\operatorname{Exp}(\beta)$ & $95 \% \mathrm{CI}$ \\
\hline \multirow[t]{10}{*}{$\mathbf{A}$} & Elevation & 0.71 & $0.33,1.51$ & 0.80 & $0.40,1.57$ & $3.74 * *$ & $1.38,10.10$ & 1.36 & $0.41,4.50$ \\
\hline & Agriculture & 0.99 & $0.97,1.02$ & 0.99 & $0.96,1.02$ & 0.98 & $0.95,1.02$ & 1.00 & $0.96,1.05$ \\
\hline & Bareland & 0.69 & $0.43,1.13$ & 1.47 & $0.98,2.19$ & 1.08 & $0.85,1.38$ & 0.56 & $0.28,1.13$ \\
\hline & Forest & 1.00 & $0.95,1.05$ & 1.00 & $0.96,1.05$ & 0.99 & $0.94,1.05$ & 0.97 & $0.92,1.03$ \\
\hline & Grassland & $1.67 * * *$ & $1.34,2.08$ & 1.14 & $0.94,1.39$ & 1.21 & $0.95,1.55$ & 1.17 & $0.85,1.62$ \\
\hline & Urbanization & 0.91 & $0.80,1.03$ & 0.77 & $0.58,1.02$ & 1.00 & $0.72,1.39$ & 0.99 & $0.70,1.42$ \\
\hline & Water & 0.91 & $0.73,1.14$ & 1.39 & $0.86,2.25$ & 0.96 & $0.66,1.39$ & $155 *$ & $1.02,235$ \\
\hline & $\begin{array}{l}\text { Distance to } \\
\text { protected area }\end{array}$ & $0.48 *$ & $0.26,0.89$ & 0.51 & $0.26,1.01$ & $0.62 *$ & $0.40,0.97$ & 0.80 & $0.35,1.84$ \\
\hline & $\begin{array}{l}\text { Distance to } \\
\text { river }\end{array}$ & 1.01 & $0.77,1.34$ & 1.22 & $0.83,1.79$ & 1.11 & $0.54,2.27$ & 0.97 & $0.64,1.46$ \\
\hline & Population & 0.99 & $0.99,1.01$ & 1.02 & $0.99,1.04$ & 0.99 & $0.97,1.01$ & 0.98 & $0.95,1.02$ \\
\hline \multirow[t]{10}{*}{ B } & Elevation & 0.56 & $0.28,1.10$ & 0.66 & $0.38,1.17$ & $2.25 *$ & $1.13,4.49$ & 0.91 & $0.43,1.94$ \\
\hline & Agriculture & 1.00 & $0.98,1.03$ & 0.99 & $0.96,1.01$ & 1.01 & $0.98,1.04$ & 1.00 & $0.97,1.04$ \\
\hline & Bareland & $0.47 * *$ & $0.30,0.73$ & 1.21 & $0.88,1.66$ & 1.08 & $0.85,1.38$ & 1.24 & $0.78,1.96$ \\
\hline & Forest & 1.01 & $0.97,1.06$ & 1.02 & $0.98,1.06$ & 1.00 & $0.96,1.05$ & 1.03 & $0.99,1.08$ \\
\hline & Grassland & $1.91 * * *$ & $1.56,2.34$ & $1.26 * *$ & $1.08,1.47$ & 1.16 & $0.94,1.42$ & $131 *$ & $1.05,1.64$ \\
\hline & Urbanization & 1.01 & $0.97,1.06$ & 0.99 & $0.79,1.24$ & 1.12 & $0.87,1.44$ & 1.04 & $0.85,1.28$ \\
\hline & Water & 0.89 & $0.74,1.07$ & 1.49 & $0.98,2.27$ & 1.04 & $0.78,1.39$ & 1.28 & $0.89,1.85$ \\
\hline & $\begin{array}{l}\text { Distance to } \\
\text { protected area }\end{array}$ & 1.25 & $0.67,2.35$ & 1.38 & $0.67,2.87$ & 1.62 & $0.97,2.72$ & 1.23 & $0.60,2.53$ \\
\hline & $\begin{array}{l}\text { Distance to } \\
\text { river }\end{array}$ & 1.02 & $0.79,1.31$ & 1.08 & $0.80,1.46$ & 1.69 & $0.90,3.16$ & 1.27 & $0.95,1.70$ \\
\hline & Population & 0.99 & $0.99,1.01$ & 1.00 & $0.99,1.02$ & 0.99 & $0.98,1.01$ & 1.00 & $0.98,1.02$ \\
\hline \multirow[t]{10}{*}{$\mathbf{C}$} & Elevation & 1.05 & $0.52,2.12$ & 1.20 & $0.70,2.08$ & 1.32 & $0.68,2.55$ & 0.89 & $0.45,1.77$ \\
\hline & Agriculture & 1.01 & $0.99,1.04$ & 1.00 & $0.98,1.03$ & 0.99 & $0.96,1.02$ & 0.99 & $0.97,1.03$ \\
\hline & Bareland & $0.62 *$ & $0.40,0.96$ & $1.37 *$ & $1.01,1.85$ & 1.08 & $0.85,1.38$ & 1.10 & $0.72,1.69$ \\
\hline & Forest & 1.00 & $0.96,1.05$ & 1.03 & $0.99,1.07$ & 1.00 & $0.96,1.04$ & 1.02 & $0.98,1.06$ \\
\hline & Grassland & $1.66 * * *$ & $1.36,2.03$ & 1.03 & $0.89,1.20$ & 1.16 & $0.95,1.42$ & 1.10 & $0.89,1.37$ \\
\hline & Urbanization & 1.02 & $0.98,1.07$ & 1.17 & $0.94,1.44$ & 1.13 & $0.88,1.45$ & 1.12 & $0.93,1.35$ \\
\hline & Water & 0.99 & $0.84,1.18$ & 1.41 & $0.93,2.14$ & 1.09 & $0.82,1.45$ & 1.08 & $0.75,1.54$ \\
\hline & $\begin{array}{l}\text { Distance to } \\
\text { protected area }\end{array}$ & 1.16 & $0.61,2.21$ & 1.10 & $0.57,2.13$ & 1.35 & $0.84,2.17$ & 1.39 & $0.72,2.68$ \\
\hline & $\begin{array}{l}\text { Distance to } \\
\text { river }\end{array}$ & 1.05 & $0.82,1.36$ & 1.20 & $0.90,1.60$ & 0.95 & $0.54,1.67$ & 1.21 & $0.93,1.59$ \\
\hline & Population & 0.99 & $0.98,1.00$ & 0.99 & $0.97,1.00$ & 0.99 & $0.98,1.01$ & 0.99 & $0.97,1.01$ \\
\hline \multicolumn{2}{|c|}{ Nagelkerke $R^{2}$} & \multicolumn{2}{|c|}{0.16} & \multicolumn{2}{|c|}{0.17} & \multicolumn{2}{|c|}{0.19} & \multicolumn{2}{|c|}{0.15} \\
\hline & $x^{2}$ & \multicolumn{2}{|c|}{159.62} & \multicolumn{2}{|c|}{105.47} & \multicolumn{2}{|c|}{104.27} & \multicolumn{2}{|c|}{43.15} \\
\hline & $P$ & \multicolumn{2}{|c|}{$<0.001$} & \multicolumn{2}{|c|}{$<0.001$} & \multicolumn{2}{|c|}{$<0.001$} & \multicolumn{2}{|c|}{0.057} \\
\hline
\end{tabular}




\section{Figure 1}

Study site and spatial pattern of land use characteristics of the extent of the study.

(A) Distribution map of wetlands surveyed from 2000 to 2015 in South Korea; 2,499 wetlands polygons were represented in black, river channels in blue, grey lines represent the boundaries of catchments. (B) Land cover map with 1:50,000 scale classified into seven categories (urban area, cropland, forest, grassland, wetland, bareland, and water). Population density in a catchment area.
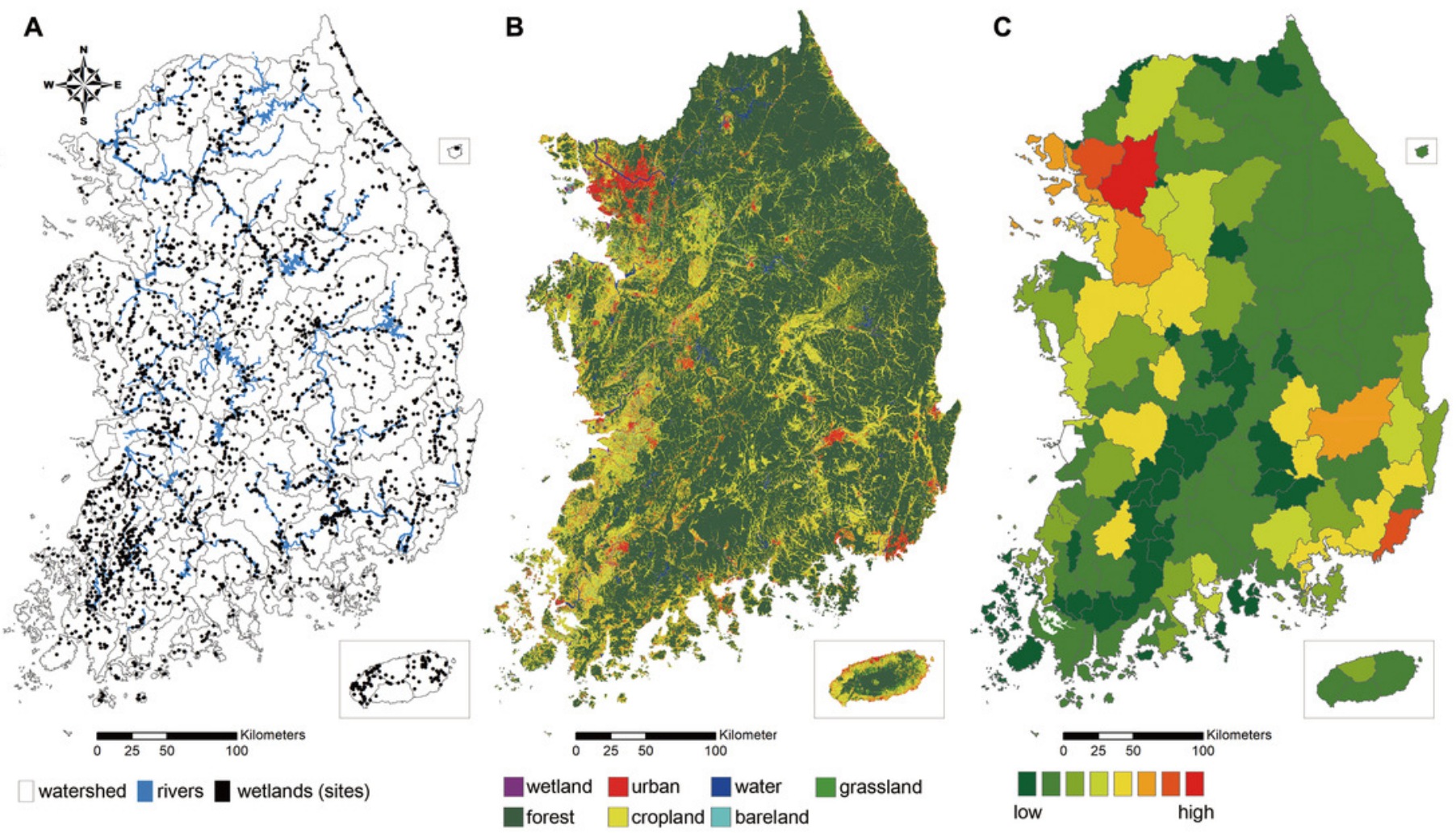
Figure 2

Area and number of wetlands with different wetland types.

More details on wetland types can be found in Table 1. The wetland area was represented with a bar graph in blue and the number of wetlands was represented by the line graph and points in black.

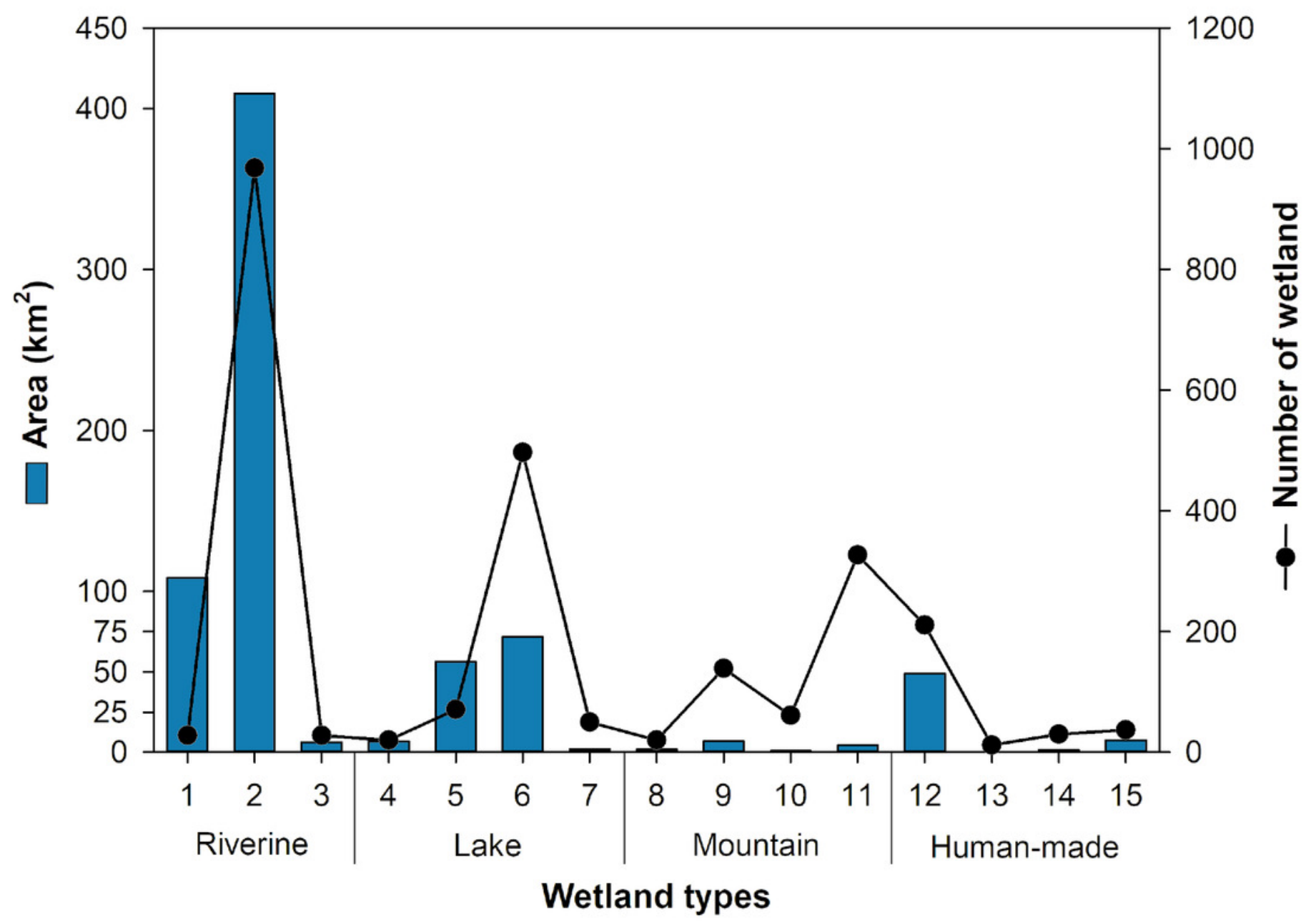




\section{Figure 3}

Spatial pattern of wetland condition rankings.

(A)-(D): point density of wetlands with different ranks (A: A rank; B: B rank; C: C rank; D: D rank); $(E)-(H)$ : relative frequency of wetland rankings $(\%)$ in the catchment area (E: A rank; F: B rank; G: C rank; H: D rank).
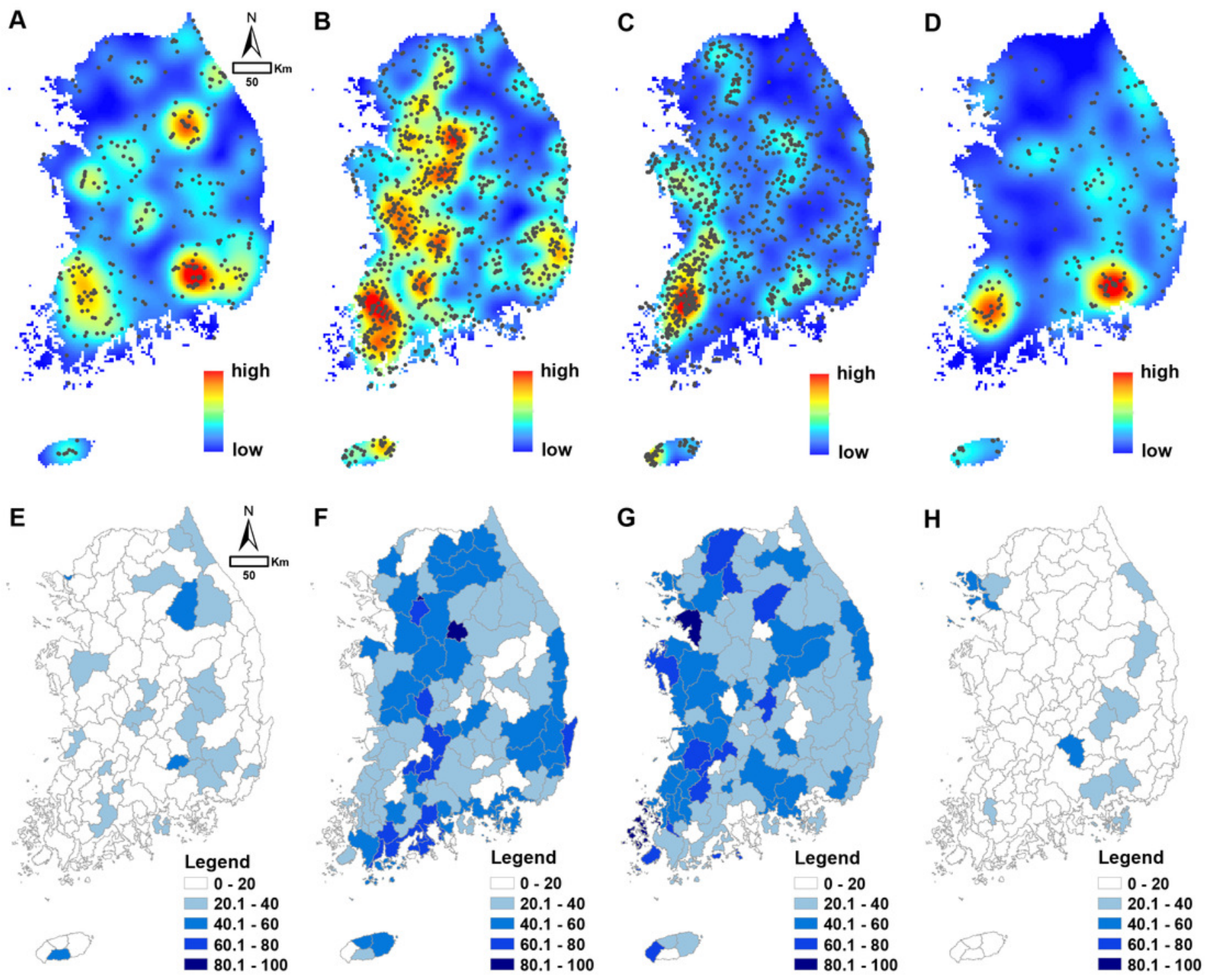


\section{Figure 4}

Relative frequency (\%) of wetland condition rankings (A-D) by various types of wetlands in South Korea (rank A: blue; B: green; C: yellow; D: red).

More details on wetland types can be found in Table 1.

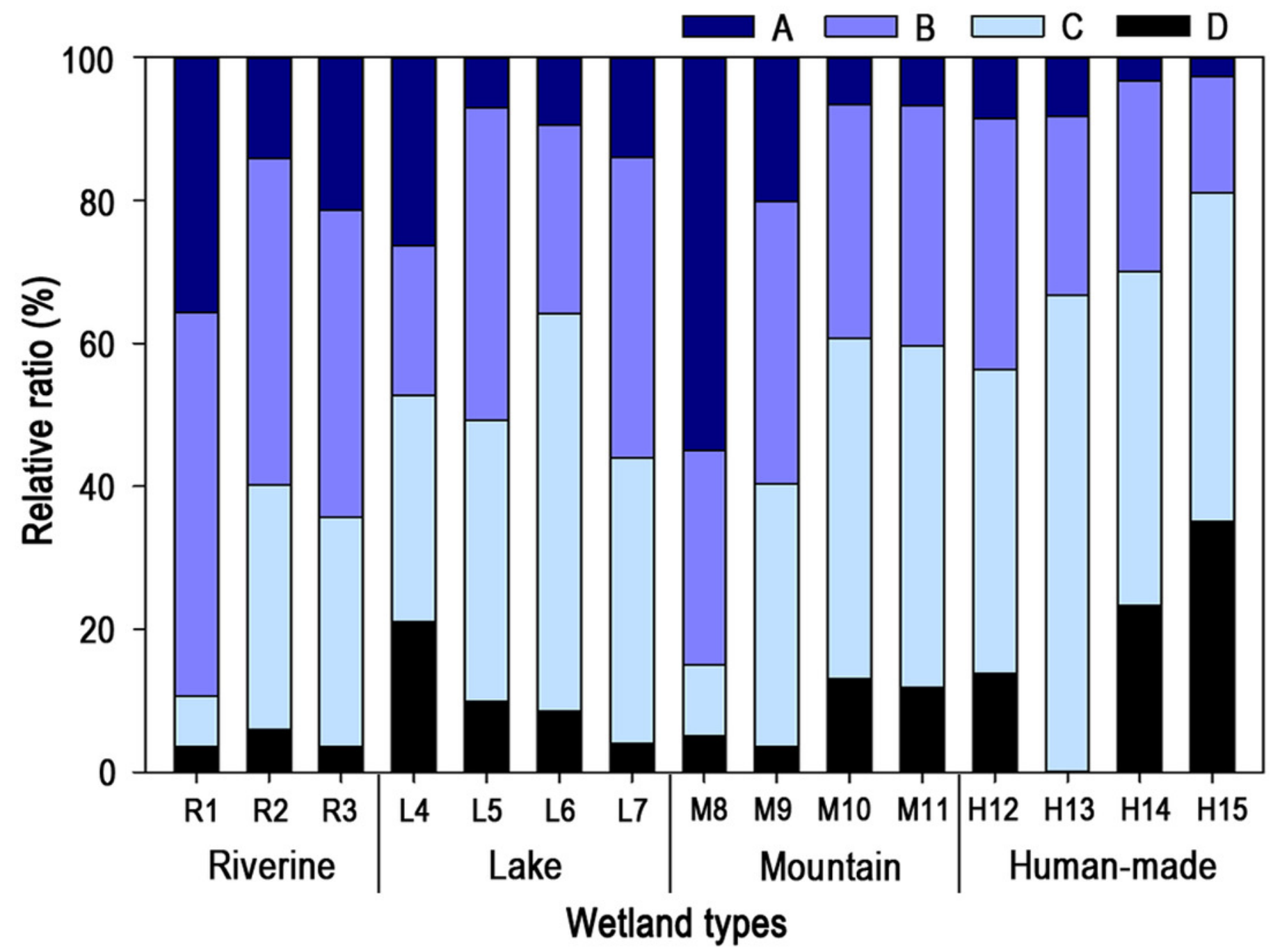

